\title{
Ecosystems: broadening the locus of value creation
}

Rahul Kapoor(D

\author{
Correspondence: kapoorr@wharton. \\ upenn.edu \\ The Wharton School, University of \\ Pennsylvania, 3620 Locust Walk, \\ Philadelphia, PA 19104-6370, USA
}

\begin{abstract}
The objective of this article is to introduce readers to the emerging research stream on business ecosystems, explicating the novelty and the usefulness of ecosystem-based theorizing, and hoping to pave the way for an influential but cumulative body of knowledge. The key tenets within an ecosystem-based perspective are outlined and used to contrast this emerging perspective from other established perspectives of value chains, supply chains, alliances, and networks. The article concludes by discussing the research approaches that can be employed to study ecosystems and the implications for organization design.
\end{abstract}

\section{Introduction}

The use of the term "ecosystem" within business settings has grown exponentially over the last decade (Fig. 1). As I have pursued a research agenda on business ecosystems during this period of increasing interest, I have faced several important questions from colleagues, reviewers, students, and attendees at seminars and conferences. Some of them seem to have been polite inquiries with the goal of understanding the contribution of the research while others seem to have been artifacts of dissonance stemming from a label or a buzzword that smells more like managerial hype rather than a legitimate object of academic inquiry. Most of the questions that I have faced can be captured by the following:

1. Is the term "ecosystem" simply a metaphor borrowed from natural sciences in order to identify a phenomenon, or is it a basis for new theory?

2. What is the difference between an ecosystem and a value chain or a supply chain?

3. How is research on ecosystems different from that on alliances or networks?

My primary objective for this article is to introduce readers to the nascent research stream on ecosystems, explicating the novelty and the usefulness of the contribution and, in so doing, offer answers to these questions above. Through this article, I also shed light on some of the challenges that accompany this emerging research paradigm and the various opportunities that exist for scholars to participate in and build this paradigm.

(c) The Author(s). 2018 Open Access This article is distributed under the terms of the Creative Commons Attribution 4.0 International License (http://creativecommons.org/licenses/by/4.0/), which permits unrestricted use, distribution, and reproduction in any medium, provided you give appropriate credit to the original author(s) and the source, provide a link to the Creative Commons license, and indicate if changes were made. 


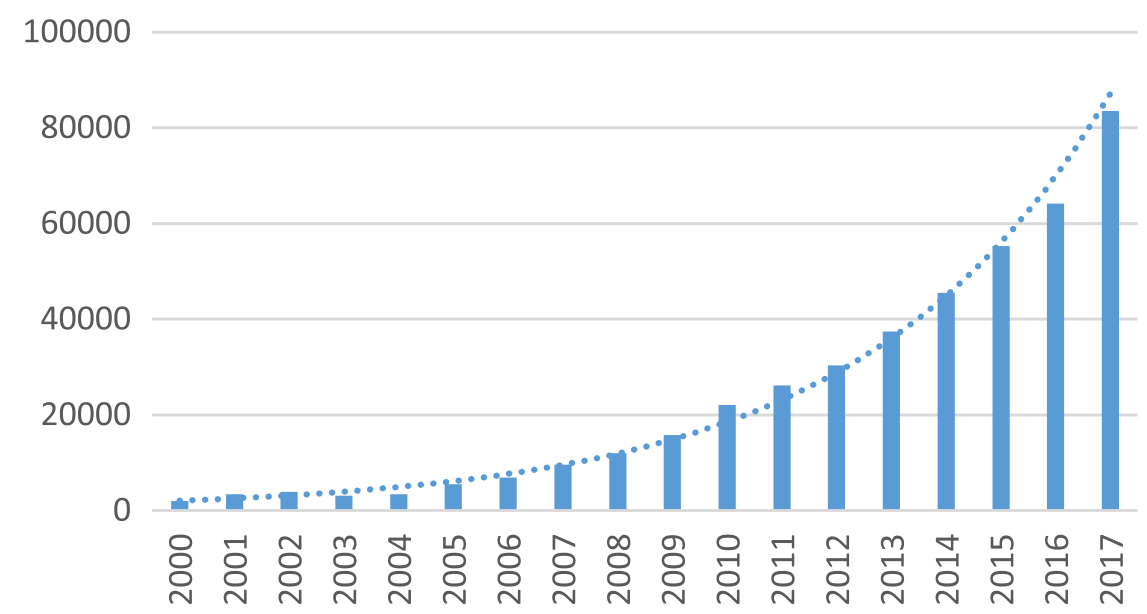

Fig. 1 Number of articles mentioning the term "ecosystem" in corporate/industrial news (Source: Factiva)

\section{Background}

The term "ecosystem" was introduced into social science by the sociologist Amos Hawley, who referred to an ecosystem as an "arrangement of mutual dependencies in a population by which the whole operates as a unit and thereby maintains a viable environmental relationship" (Hawley 1986; p. 26). In the field of business strategy, the term was first introduced by Moore (1993), who invoked the notion that firms be viewed not as members of a single industry but rather as members of a business ecosystem comprising of firms from a variety of industries and that business ecosystems, like biological ecosystems, evolve over time with implications for their members in terms of innovation, cooperation, and competition. Since then, many definitions of ecosystem have been advanced emphasizing different aspects of the ecosystem, and they are not always fully compatible.

Simply put, an ecosystem encompasses a set of actors that contribute to the focal offer's user value proposition.

The offer could be a product or a service, designed with or without a platform-based technological architecture. The key to this definition is the explicit link between the supply-side and the demand-side of a focal offer and the consideration of the different types of actors from multiple industries that contribute towards a focal offer's value creation. For example, actors' contributions could be with respect to the focal offer itself (e.g., electric car), the upstream component offers (e.g., batteries, electronics, motors) that are integrated within the focal offer, and the downstream complement offers (charging stations, garages) that are integrated with the focal offer by the user (Adner and Kapoor 2010). Focal offer can be defined as narrowly such as Tesla's Model 3 or as broadly such as the electric car or somewhere in between such as Tesla's electric car. The scope of the focal offer considered is based on the line of inquiry, which could be at the level of the innovation, the technology, the firm, or the ecosystem. In general, for the ecosystem analysis to be useful, the focal offer should not be too broad such that there is little overlap between the upstream component and downstream complement offers. For example, it is better to analyze the battery electric car ecosystem separately from the fuel cell car ecosystem than to aggregate the two offers into zero-emission vehicle ecosystem. 
The main theoretical premise for ecosystem research is the simultaneous presence of complementarities and interdependencies between actors. Complementarities between actors stem from the fact that the functions performed by their respective offers help to create or enhance the user value proposition. Interdependencies between actors stem from the fact that their offers are connected within a system-level architecture. While complementarities represent an economic relationship between offers in terms of the potential for value creation, interdependencies represent a structural relationship between offers in terms of how they are connected for the value to be created and how a change in one offer may affect the contribution of other offers towards value creation.

For example, consider the electric car as a focal offer in the electric car ecosystem. The complementarities between electric cars and the charging infrastructure, as well as between batteries and electric cars, are rather obvious. However, the structure of interdependence between batteries and electric cars is distinct from the structure of interdependence between electric cars and the charging infrastructure. Batteries and electric cars are directly connected via a component-product upstream interaction whereas charging infrastructure and electric cars are indirectly connected via the downstream user interaction. Moreover, there are important interdependencies between batteries and charging infrastructure as well as between charging infrastructure and the electricity grid that are typically not revealed based on the analysis of complementarities. Improvements in batteries can enhance the contribution of the charging infrastructure towards an electric car's value creation, and improvements in the charging infrastructure could hold back the contribution if the electricity grid is not optimized for increased usage especially during peak hours.

The core concern for research grounded in an ecosystem perspective is to explain firms' strategies and outcomes through the lens of such complementarities and interdependencies (e.g., Adner and Kapoor 2010, 2016; Kapoor and Lee 2013; Kapoor and Agarwal, 2017; Hannah and Eisenhardt 2017; Adner 2017; Jacobides et al. 2018; Baldwin, 2018a).

\section{Value chain and supply chain perspectives}

Value chain and supply chain perspectives are significantly different from an ecosystem perspective in terms of both their focus and their line of inquiry. Porter (1985) introduced the concept of a value chain to analyze the sources of a firm's competitive advantage. He described the value chain as:

Competitive advantage cannot be understood by looking at a firm as a whole. It stems from the many discrete activities a firm performs in designing, producing, marketing, delivering and supporting its product. Each of these activities can contribute to a firm's relative cost position and create a basis for differentiation...[E]very firm is a collection of activities that are performed to design, produce, market, deliver, support its product. All these activities can be represented using a value chain

As this description makes it clear, a value chain perspective is centered on the focal firm, which is viewed through a set of discrete activities. These activities jointly determine a firm's cost and the value that its offer creates for the customer. Value chain analysis has been the primary form of "micro-analytics" for academics, consultants, and 
managers to examine how different firms compete in terms of cost and differentiation in a given market (also referred to as a firm's competitive position) and how value chain choices shape a firm's competitive advantage. An important theoretical consideration within the value chain perspective is the interdependence among activities underlying a firm's value chain such that the firm's competitive advantage stems from how the different activities fit together (Porter 1996; Siggelkow 2001; Rivkin 2000). Hence, the core concern for research grounded within a value chain perspective is to analyze firms' competitive position with respect to its rivals and to explain how value chain choices help firms create and sustain their competitive advantage. Both the value chain and the ecosystem perspectives are explicit about the importance of the demand-side in terms of how firms create value and the need to take into account the different "elements" that contribute to value. However, while the ecosystem perspective takes a macro view of the external actors that contribute to the focal firm's value creation, the value chain perspective takes a micro view of the firm's internal activities that underlie its performance relative to its competitors. ${ }^{1}$

Supply chain perspective has its origins dating back to the invention of the assembly line, but the perspective came to prominence during the 1990s within the field of operations (Lee et al. 1997; Fisher 1997; Mentzer et al. 2001). A supply chain as the name suggests is a chain of actors directly involved in the upstream and downstream flows of inputs and outputs from a source to a customer such as the one captured in the classic beer distribution game (Sterman, 1989). The core concern for research on supply chains is to understand the coordination challenges between upstream and downstream actors (e.g., suppliers, distributors, retailers, customers) and to create a supply chain that is efficient and responsive to demand volatility. Within this perspective, management scholars have focused on studying buyer-supplier relationships through both formal and relational governance (e.g., Dyer 1997; Helper et al. 2000) as well as through firms' make-or-buy decisions (e.g., Poppo and Zenger 1998). Hence, while a supply chain perspective emphasizes the set of upstream and downstream actors that underlie the input-output flows for a focal product, it focusses on managing supply-side interactions in terms of efficiency and responsiveness without any consideration of the complementarities on the demand-side and the structure of the interdependencies.

Each of these perspectives is valuable in explaining different aspects of how firms compete and create value, take for example, Apple's iPhone offer that has been one of the biggest successes of the internet era. Apple has pursued a differentiation-based (not cost-based) competitive advantage that is enabled by its internal set of activities related to design, R\&D, marketing, manufacturing, distribution, and of course, leadership. Apple has drawn on a global supply chain of hardware and assembly suppliers for the development of new generations of iPhone and for matching the supply with demand (Johnson and Mark 2017). Finally, one would be remiss in not viewing Apple's iPhone through an ecosystem perspective. Apple pursued an integrated hardware and software platform architecture with its iPhone offer, where app developers, manufacturers of accessories, and other service providers contributed significantly to the iPhone's user value proposition. It is the leveraging of complementarities and managing of interdependencies with these external actors that has been a key aspect of how Apple has competed and created value through the iPhone (Adner, 2012). 


\section{An ecosystem perspective as a basis for new theory}

Value creation in an ecosystem is enabled by the presence of complementarities and interdependencies between actors, whose offers contribute to the focal offer's user value proposition. This co-occurrence of the economic and structural relationships between actors forms the basis for new research questions and new theory.

Interdependencies represent a structural relationship between actors in terms of how their offers are connected for the value to be created. At the most basic level, an actor is connected with the focal actor if its offer influences the focal offer's value proposition because of function-level interactions (e.g., battery and electric car, charging station and electric car). In addition, actors can also be connected via a transaction such that an output (i.e., offer) of one actor is an input to another actor. While a transactionlevel connection is not a necessary condition for the two actors to be structurally interdependent in an ecosystem, the way the transactions are organized in an ecosystem impact the roles played by the different actors in the ecosystem.

For example, let us consider a focal offer A, and that is connected with offers B and $\mathrm{C}$ for value to be created at the point of use. In terms of functionality, offer A could be a hardware product, offer B could be an operating system, and offer C could be a software application. Alternatively, offer A could be an electric car, offer B could be the battery, and offer $\mathrm{C}$ could be the charging infrastructure. Let us assume that each of these offers is produced by specialized firms.

In terms of transactions, there are many possibilities with respect to how the input-output flows may be organized in an ecosystem. Users could integrate offers A, $B$, and C. Such a configuration would entail three different transactions, each between an upstream firm producing the offer $(\mathrm{A}, \mathrm{B}$, or $\mathrm{C})$ and the downstream user. Under this configuration, firms producing each of the offers play the role of complementors to each other. Alternatively, a fourth firm could integrate offers A, B, and C and transfer the integrated offer to the user. Such a configuration would entail four different transactions, each between an upstream firm producing the offer $(\mathrm{A}, \mathrm{B}$, or $\mathrm{C})$ and the downstream integrator firm $(A+B+C)$ and another transaction between the integrator firm and the downstream user. Under this configuration, besides firms producing each of the offers playing the role of complementors to each other, they are also suppliers to the downstream integrator firm, which itself is a supplier to the user.

In addition to these two archetypical configurations, there are a number of input-output flow configurations in which the locus of integration for any combination of offers $\mathrm{A}, \mathrm{B}$, and $\mathrm{C}$ could take place at the point of use or by upstream firms. For example, an integrator firm could integrate offers $A$ and $B$, and the user integrates offer $C$ with $A B$. Under this configuration, producers of offers $A$ and $B$ are suppliers to the integrator firm, and the producer of offer $\mathrm{C}$ is a complementor to the integrator firm.

Note that the locus of integration in an ecosystem is a separate construct from that of the scope of integration. The locus of integration is an ecosystem-level construct that is based on the flow of inputs and outputs in an ecosystem, and the integrator is an actor that bundles inputs. Hence, the integrator has decision rights over the downstream bundling of different offers that are produced upstream with an ecosystem. In contrast, the scope of integration is a firm-level construct that is based on the production of different offers within an ecosystem. An important strategic choice for a firm in an ecosystem is 
whether to expand its scope and produce different offers that underlie the focal offer's value proposition (e.g., Gawer and Henderson 2007; Kapoor and Lee 2013).

These characterizations in terms of what is connected to what within the technological architecture (both supply- and demand-side) and who does what within the production architecture of input-output flows represent the basis for new research questions and new theory. Accordingly, research on ecosystems pays particular attention to the activities that make up the different offers, the actors who undertake those activities and produce those offers, and the technology and production architectures that connect offers and actors respectively (Table 1). Below, I highlight three theoretical objects of inquiry-bottlenecks, complementors, and platforms that operate at the level of the activities, the actors, and the architectures respectively, and that are salient to the extant research on ecosystems.

\section{Bottlenecks}

Any system composed of multiple components is subject to bottlenecks that constrain the performance of the system. In an ecosystem, bottlenecks are component offers in the ecosystem whose performance, cost, or scarcity constrains the focal offer's value proposition, thereby limiting its demand or growth. For example, within the electric car ecosystem, the performance of the batteries in terms of dollars per kilowatt and the scarcity of charging infrastructure in terms of geographical density, time, or cost for charging are major bottlenecks for the electric car value proposition for the mainstream user to materialize. Further, as the adoption of electric car accelerates, in part because of improvements in batteries and charging infrastructure, the electricity grid could become a bottleneck because of greater demands stemming from electric car charging. As this example illustrates, an ecosystem can have multiple bottlenecks that can lie upstream or downstream within the architecture of input-output flows, and that bottlenecks can change over time.

Table 1 Considerations for ecosystem research

\begin{tabular}{|c|c|c|c|}
\hline Level & Definition & $\begin{array}{l}\text { Example } \\
\text { (electric car ecosystem) }\end{array}$ & $\begin{array}{l}\text { Example } \\
\text { (smartphone ecosystem) }\end{array}$ \\
\hline Activities & $\begin{array}{l}\text { Tasks that underlie the } \\
\text { different offers that } \\
\text { contribute to the focal } \\
\text { offer's user value } \\
\text { proposition }\end{array}$ & $\begin{array}{l}\text { Electric car manufacturing, } \\
\text { battery manufacturing, } \\
\text { installation of charging stations, } \\
\text { maintenance, and repair }\end{array}$ & $\begin{array}{l}\text { Handset manufacturing, } \\
\text { hardware component } \\
\text { manufacturing, operating } \\
\text { system development, software } \\
\text { applications development, } \\
\text { wireless service provision }\end{array}$ \\
\hline Actors & $\begin{array}{l}\text { Agents who undertake } \\
\text { activities and produce the } \\
\text { different offers }\end{array}$ & $\begin{array}{l}\text { Electric car manufacturers, } \\
\text { battery manufacturers, charging } \\
\text { service providers, garages }\end{array}$ & $\begin{array}{l}\text { Manufacturers of hardware } \\
\text { components and handsets, } \\
\text { developers of operating system } \\
\text { and software applications, } \\
\text { providers of wireless service }\end{array}$ \\
\hline Architectures & $\begin{array}{l}\text { Technological interactions } \\
\text { between offers and input- } \\
\text { output flow interactions } \\
\text { between actors }\end{array}$ & $\begin{array}{l}\text { Product-based; battery and } \\
\text { electric car, charging station } \\
\text { and electric car; battery } \\
\text { manufacturers as suppliers } \\
\text { and charging service providers, } \\
\text { and garages as complementors }\end{array}$ & $\begin{array}{l}\text { Platform-based between apps } \\
\text { and operating system. Product- } \\
\text { based between hardware } \\
\text { components, wireless service, } \\
\text { and handset; app developers as } \\
\text { platform-based complementors, } \\
\text { wireless service providers as } \\
\text { product-based complementors, } \\
\text { hardware component } \\
\text { manufacturers as suppliers }\end{array}$ \\
\hline
\end{tabular}


The technological architecture can also create system-level interactions between the different components such that an improvement in one component can exacerbate or mitigate the constraints imposed by other components. For example, improvement in batteries for electric cars can mitigate the constraints imposed by the charging infrastructure, as users would be less likely to suffer from range anxieties. In contrast, improvements in the charging infrastructure could exacerbate the constraints imposed by the electricity grid, as more users would be drawing on the charging infrastructure.

A key aspect of research on ecosystems is to identify the bottlenecks in the ecosystem stemming from innovations in technologies and business models and to illustrate how they impact firms (Adner and Kapoor 2016; Kapoor and Furr 2015). It is also important to consider how firms may allocate resources to resolve bottlenecks in their ecosystems through R\&D investments, alliances, or even integration into the activities underlying the bottleneck component (Ethiraj 2007 Adner and Kapoor 2016; Hannah 2016; Zobel et al. 2017). Other strategic choices entail choosing markets or technologies where bottlenecks are either relatively easily resolvable or where firms' control over the bottleneck component may provide it with a source of rents (Baldwin 2018b). Finally, an important implication of the existence of bottlenecks in an ecosystem is that firms would need to develop architectural knowledge not only at the level of the product (Henderson and Clark 1990) but also at the level of the ecosystem. Such knowledge can enable firms to recognize bottlenecks and can provide an important source of competitive advantage as evidence through Edison's success with electric lighting (Hughes 1993).

\section{Complementors}

Complementors represent a key role played by firms in an ecosystem. These are the actors who produce complementary products and services that contribute towards the focal offer's value creation (e.g., apps for smartphone, charging infrastructure for electric cars, physician services for hospitals). The nature of interdependence between firms and their suppliers is distinct from that of firms and their complementors. The former is characterized by a supply-side sequential interdependence with the firm having the decision rights with respect to the integration of upstream input into the focal offer whereas the latter is characterized by a demand-side pooled interdependence with the downstream actor (or user) having the decision rights with respect to the integration of the complements with the focal offer (Fig. 2). This difference has important theoretical implications for firms in at least three fundamental ways.

First, a primary consideration for a firm with respect to suppliers is to create a dyadic governance structure, drawing on formal and relational mechanisms, for effective coordination between the firm and the supplier (e.g., Dyer 1997; Poppo and Zenger 1998). In contrast, the primary consideration with respect to complementors is to create an "alignment structure" (Adner 2017), typically multilateral, that ensures joint-value creation and mitigates conflicts over value capture over time (Gawer and Henderson 2007 Casadesus-Masanell and Yoffie 2007; Kapoor, 2013; Kapoor and Lee 2013; Altman 2016). The alignment structure may not only entail the use of formal and relational mechanisms to coordinate the respective 
Supplier

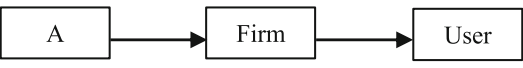

Complementor

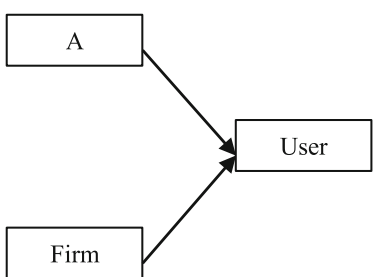

Fig. 2 Different roles in an ecosystem: supplier vs. complementor

activities but also mutual agreement in terms of the standards for interoperability, the respective business models around who does what, and what is the distribution of value capture within the integrated bundle of the focal offer and complements.

Second, based on the function performed by the complement, it could vary in terms of how it contributes to the focal offer's value proposition (Baldwin, 2018a; 2018c; Jacobides et al. 2018). The focal offer and the complement can have no standalone value except in joint-use such as razor and blade or mobile phone and mobile operating system. This has been referred to as strong or strict complementarity (Hart and Moore 1990). Alternatively, complement could exhibit supermodular complementarity (Milgrom and Roberts 1990), such that more of the complement (i.e., in terms of performance/cost, availability) could enhance the value proposition of the focal offer such as apps for smartphone or charging stations for electric car. Further, complements could be generic or specialized with respect to the focal offer (Teece 1986). These differences in complementarities can have a significant impact on the challenges that firms may face in terms of creating an alignment structure and in ensuring that the focal offer's value proposition is materialized.

Finally, firms typically have well-specified internal organizational designs to manage the buyer-supplier relationships through procurement, marketing, and sales functions. In many ecosystems, firms neither buy from nor sell to complementors. At the same time, coordination of activities with complementors can entail both upstream (e.g., R\&D) and downstream (e.g., marketing) activities which increases the organizational design complexity. Hence, managing complementors may present an important organization design challenge in terms of the interfaces and the processes that firms may use to effectively manage their interdependence over time (e.g., Kapoor 2014).

\section{Platforms}

Many ecosystems are organized around a central platform-based architecture that serves as a foundation for firms to offer complementary products or services. ${ }^{2}$ There 
are several important differences between a product-based and a platform-based ecosystem. Platform-based ecosystems are orchestrated by the owner of the platform, who creates the platform architecture and sets the rules for complementors to participate in the ecosystem (e.g., Gawer and Cusumano 2002; McIntyre and Srinivasan 2017; Baldwin, 2018d). Accordingly, the alignment structure between the platform firm and the complementors is determined by the platform owner. In contrast, the alignment structure between the product firm and complementors is typically mutually determined. ${ }^{3}$

Platform owners also determine the architectural design of the platform in terms of the interfaces that enable complements to connect with the platform and how the design evolves over time to improve the functionality of the platform (e.g., introduction of new platform generations). These architectural design choices have important implications not only for the platform firms themselves but also for the complementor firms (Boudreau 2010; Kapoor and Agarwal 2017; Agarwal and Kapoor, 2018). Because each platform is associated with unique interfaces that requires complementors to make specialized investments, complementors have a choice to be a part of a specific platform-based ecosystem. Accordingly, an important strategic decision for complementors is to decide which platforms to embrace and whether to be active on multiple platforms (e.g., single vs. multihoming). The decision to multihome needs to account for increasing the market opportunities but also the costs of designing a complement that functions well on multiple platforms. From a platform firm perspective, greater use of multihoming by complementors also reduces the relative value proposition of the focal platform with respect to the rival platforms. Hence, research on platform-based ecosystems is not only about studying the strategies and performance of platform firms but also those of the complementors.

Product-based ecosystems entail a single-sided market interaction between the product firm (i.e., the supplier) and the user (i.e., the buyer) whereas platform-based ecosystems entail two- or multi-sided markets where the platform firm interacts with complementors and users as different markets with cross-side network effects (i.e., value to actors on one side depends on the actors on the other side). This multi-sided market interaction becomes a critical aspect of the alignment structure, entailing pricing and subsidies, that platform firms have to determine so as to enhance the value proposition of the platform (e.g., Rochet and Tirole 2006; Parker and Van Alstyne 2014).

These differences between product-based and platform-based ecosystems suggest that managing interdependencies between firms and complementors in platform-based ecosystems takes a very different form than those in product-based ecosystems. The "hub-and-spoke" interdependence between platform firm and complementors is managed through one-size fits all formal market-based governance mechanisms set by the platform firm. In contrast, the "point-to-point" interdependence between product firms and their complementors is managed through a combination of formal and relational governance mechanisms, which could be customized for different actors. Perhaps more importantly, these differences also suggest that making a shift from a product-based to a platform-based architecture requires a fundamental change not only in terms of the firm's business model but also in terms of its capabilities, governance, and even identity (e.g., Altman and Tripsas 2015; Van Alstyne et al. 2016; Helfat and Raubitschek 2018). 
In summary, the core tenet for research on ecosystems is to consider the relationships between actors that contribute to the focal offer's user value proposition. These relationships have both an economic and a structural component. Identifying the structural relationships of how the offers interact with respect to the value proposition, and how the actors interact with respect to value creation is a hallmark of research on ecosystems. As the discussion above details, bottlenecks, complementors, and platforms represent unique theoretical objects of inquiry at the level of the activities, the actors, and the architectures that make up the ecosystem. Accordingly, research can be conducted at the level of the focal offer (innovation, technology), at the level of the focal firm, and at the level of the ecosystem.

\section{Strategic alliances vs. strategic networks vs. business ecosystems}

The strategy literatures on alliances, networks, and ecosystems each have a common theme that firms are not islands. Rather, firms are dependent on other firms for creating value. However, each of the literatures focus on unique aspects of this interdependence (summarized in Table 2). The alliance literature considers how firms voluntarily cooperate with other firms and underscores the importance of alliance governance and firms' capabilities to manage alliances (Gulati, 1998; Kale and Singh, 2009). The strategic networks literature is rooted in a sociological perspective and underscores how the social structure of ties, predominantly ties that are formed through strategic alliances, can confer firms with an advantage in terms of information, resources, and status (Podolny and Page 1998; Gulati et al., 2000). Hence, the starting point for both of these literatures is the act of firms voluntarily collaborating with other firms. While the alliance literature focusses on how firms can benefit from the dyadic tie, the network literature focusses on how firms can benefit from the structure of such dyadic ties with multiple firms that form the network.

The starting point for ecosystem research is the focal offer (e.g., electric car, smartphone, software application), not the focal firm or the alliance. The primary research focus is on recognizing the linkages between the activities and the actors that

Table 2 Distinctions between strategy research on alliances, networks, and ecosystems

\begin{tabular}{|c|c|c|c|}
\hline & Strategic alliances & Strategic networks & Business ecosystems \\
\hline Definition & $\begin{array}{l}\text { Voluntary arrangements } \\
\text { between firms involving } \\
\text { exchange, sharing, or } \\
\text { codevelopment of products, } \\
\text { technologies, or services } \\
\text { (Gulati 1998). }\end{array}$ & $\begin{array}{l}\text { Strategic networks are } \\
\text { composed of } \\
\text { interorganizational ties } \\
\text { that are enduring, are of } \\
\text { strategic significance for } \\
\text { the firms entering them, } \\
\text { and include strategic } \\
\text { alliances, joint ventures, } \\
\text { long-term buyer-supplier } \\
\text { partnerships, and a host } \\
\text { of similar ties (Gulati, } \\
\text { Nohria, and Zaheer, 2000) }\end{array}$ & $\begin{array}{l}\text { Set of actors that contribute } \\
\text { to the user value proposition } \\
\text { of a focal product or service, } \\
\text { designed with or without a } \\
\text { platform-based technological } \\
\text { architecture }\end{array}$ \\
\hline $\begin{array}{l}\text { Connections } \\
\text { between firms }\end{array}$ & Alliance & Alliance & $\begin{array}{l}\text { Interdependence between } \\
\text { activities/technologies }\end{array}$ \\
\hline Unit of analysis & Firm or alliance & $\begin{array}{l}\text { Firm or network } \\
\text { (typically alliance) }\end{array}$ & Innovation or firm or ecosystem \\
\hline $\begin{array}{l}\text { Key theoretical } \\
\text { considerations }\end{array}$ & $\begin{array}{l}\text { Alliance governance } \\
\text { (formal/relational), } \\
\text { alliance capability, } \\
\text { partners' resources }\end{array}$ & $\begin{array}{l}\text { Structure of ties, access to } \\
\text { information, status, brokerage } \\
\text { (information, resources), } \\
\text { embeddedness }\end{array}$ & $\begin{array}{l}\text { Structure of interdependence } \\
\text { (technology, inputs-outputs), } \\
\text { complements, bottlenecks, } \\
\text { platforms }\end{array}$ \\
\hline
\end{tabular}


contribute to the focal offer's value proposition and how they impact focal firms' strategies and performance outcomes. The strategies correspond to choices that are available to firms for coordinating and aligning interdependent activities. Prominent among them are choices with respect to firms' boundaries and alliances (e.g., Gawer and Henderson 2007; Kapoor and Lee 2013; Kapoor, 2013; Kapoor and McGrath 2014; Hannah and Eisenhardt 2017) and choices that help balance cooperation and competition among actors in the ecosystem such as through pursuing complementary business models (Casadesus-Masanell and Yoffie 2007; Ansari, Garud, and Kumaraswamy, 2016) and through disclosure of some, but not all, intellectual property during standard setting (Toh and Miller 2017). The strategies can also correspond to choices with respect to the focal offer itself (e.g., technology, platform) that may involve tradeoffs with respect to superior performance of the focal offer but with the likelihood of bottlenecks in the ecosystem that could prevent its value proposition from materializing (Adner and Kapoor 2010; Kapoor and Furr 2015; Agarwal and Kapoor, 2018).

Hence, while creating and managing a network of alliances is an important aspect of how firms could manage interdependent activities in an ecosystem, this aspect is a subset of considerations and choices that are available to firms embedded in an ecosystem. Moreover, the structural considerations in the literature on strategic networks are based on the interorganizational structures that are formed through alliances between firms and the benefits that they may accord to firms in terms of resources, information, and status. The structural considerations in ecosystems are based on how the different activities and actors interact with respect to the focal offer's value proposition and how that may constrain or facilitate the focal offer's value creation.

\section{Researching an emerging paradigm}

Research on ecosystems represent an emerging paradigm (Kuhn 1962), in which researchers have yet to converge on concepts, assumptions, mechanisms, and approaches. The lack of convergence, in part, stems from differences in research objectives and questions. In part, it stems from the significant theoretical and methodological challenges that accompany such a research endeavor. Often times, the research is framed as research on ecosystems so as to be deemed relevant and important, but the research question, the theoretical development, and the empirical analysis do not consider the interdependencies with respect to the different offers that contribute to the focal offer's user value proposition or the need for coordination and alignment with respect to complementors. ${ }^{4}$ Absent those considerations, it is difficult to assess why an ecosystembased perspective is required for that research in the first place.

In many cases, however, scholars have explicitly considered ecosystem-level interdependencies to explore phenomenon that have been studied within established literatures such as first-mover advantage (Adner and Kapoor 2010), technology substitution (Adner and Kapoor 2016), technology standards (Toh and Miller 2017), industry evolution (Kapoor and Furr 2015), firm boundaries, and alliances (Kapoor and Lee 2013; Hannah and Eisenhardt 2017). This research approach draws on ecosystem-level mechanisms such as those with respect to bottlenecks and complements to highlight the value of these mechanisms to explain firms' strategies and performance outcomes.

In other cases, scholars have begun to pursue the development of ecosystem-level theories that take into account the structural interdependencies and complementarities 
to shed light on new sets of questions (Adner 2017; Jacobides et al. 2018). Some of these questions pertain to technological and strategic interactions between the platform firms and complementor firms (Gawer and Henderson 2007; Kapoor and Agarwal, 2017; Wen and Zhu 2017; Rietveld et al. 2017), the innovativeness of different actors in the ecosystem (Ganco et al. 2018), and the managerial cognitive biases with respect to interdependencies in ecosystems (Adner and Feiler 2018).

As scholars pursue these and other avenues of research, they confront significant theoretical and methodological challenges. At the most basic level, ecosystems represent actors connected via a technological architecture and economic transactions entailing both supply- and demand-side interactions. Accordingly, theorizing in ecosystems requires an interdisciplinary approach and being supported by multiple methods (archival, quantitative, qualitative, formal and computational modeling, experiments). In addition, pursuing empirical research in ecosystems entails developing a high level of contextual knowledge and typically hand collecting data from a variety of sources (e.g., Adner and Kapoor 2010). Accordingly, researchers tend to focus on a specific empirical setting to explore their research questions.

Table 3 lists several examples of the empirical studies and details the setting, the data sources, and the operationalization of key constructs within the nascent stream of research on ecosystems. Scholars have drawn on a variety of settings (PC, semiconductor, healthcare, solar power, smartphone) to highlight ecosystem-level mechanisms related to bottlenecks, complementors, and platforms in explaining firms' strategies and their outcomes. Almost all of these studies have drawn on context-specific data sources to measure and operationalize ecosystem constructs. As scholars expand into new lines of inquiry, new types of data sources may have to be leveraged. For example, in many software-based ecosystems, technological interdependencies can be mapped by observing data with respect to application programming interfaces (APIs). Input-output tables that capture interindustry flows (Leontief 1986) could provide another valuable source of data to map and study ecosystem-level interdependencies.

\section{Implications for organization design}

Ecosystems represent an increasingly prevalent organizational form that is a departure from the Chandlerian firm, the long-standing focus of the field of organization design. This shift presents new considerations for organizational design at the level of the ecosystem, at the level of the actors, and at the level of the underlying activities that make up the different offers.

The design of the ecosystem in terms of the technological architecture and in terms of the input-output flows have a significant impact on how value gets created in an ecosystem, the roles played by the different actors, and the interdependencies between them. For example, a platform-based ecosystem represents a distinct organizational design configuration than a product-based ecosystem, and this distinction has implications for how firms compete and create value such as the cases of Research in Motion's BlackBerry and Apple's iPhone offers. Moreover, how ecosystems come about, whether through a process of disaggregation from integrated firms to specialized firms, or whether through a process of aggregation in which new or existing components 
Table 3 Different empirical research designs used for ecosystem research

\begin{tabular}{|c|c|c|c|c|}
\hline $\begin{array}{l}\text { Representative } \\
\text { studies }\end{array}$ & $\begin{array}{l}\text { Ecosystem } \\
\text { construct }\end{array}$ & Setting & Selected data sources & $\begin{array}{l}\text { Operationalization of } \\
\text { ecosystem construct }\end{array}$ \\
\hline Ethiraj (2007) & Bottleneck & $\begin{array}{l}\text { Personal } \\
\text { computer (PC) } \\
\text { components }\end{array}$ & $\begin{array}{l}\text { Industry journals, PC } \\
\text { Magazine, and PC } \\
\text { World }\end{array}$ & $\begin{array}{l}\text { Component constraints } \\
\text { identified in the product } \\
\text { reviews }\end{array}$ \\
\hline $\begin{array}{l}\text { Adner and } \\
\text { Kapoor (2010) }\end{array}$ & $\begin{array}{l}\text { Bottleneck } \\
\text { (suppliers, } \\
\text { complementors) }\end{array}$ & $\begin{array}{l}\text { Semiconductor } \\
\text { lithography }\end{array}$ & $\begin{array}{l}\text { Industry journal, Solid } \\
\text { State Technology; } \\
\text { Interviews }\end{array}$ & $\begin{array}{l}\text { Count of articles that } \\
\text { discuss the technical } \\
\text { problems in components } \\
\text { and complements }\end{array}$ \\
\hline $\begin{array}{l}\text { Kapoor and } \\
\text { Lee (2013) }\end{array}$ & $\begin{array}{l}\text { Organizational } \\
\text { form for } \\
\text { complementors }\end{array}$ & Healthcare & $\begin{array}{l}\text { American Hospital } \\
\text { Association annual } \\
\text { surveys }\end{array}$ & $\begin{array}{l}\text { Hospital-physician } \\
\text { organizational form } \\
\text { (arm's length, alliance, } \\
\text { integrated) }\end{array}$ \\
\hline $\begin{array}{l}\text { Hannah and } \\
\text { Eisenhardt (2017) }\end{array}$ & Bottleneck & $\begin{array}{l}\text { Residential solar } \\
\text { system }\end{array}$ & $\begin{array}{l}\text { Interviews; newspaper } \\
\text { and magazine articles, } \\
\text { blogs, analyst reports }\end{array}$ & $\begin{array}{l}\text { Component that most } \\
\text { constrains the growth or } \\
\text { performance of the } \\
\text { ecosystem due to poor } \\
\text { quality, poor performance, } \\
\text { or short supply }\end{array}$ \\
\hline $\begin{array}{l}\text { Kapoor and } \\
\text { Furr (2015) }\end{array}$ & Bottleneck & $\begin{array}{l}\text { Solar } \\
\text { photovoltaic (PV) }\end{array}$ & $\begin{array}{l}\text { Industry journal, } \\
\text { Photon International } \\
\text { annual equipment } \\
\text { surveys }\end{array}$ & $\begin{array}{l}\text { Commercially availability of } \\
\text { deposition and contact } \\
\text { equipment in an emerging } \\
\text { industry }\end{array}$ \\
\hline Zobel et al. (2017) & Bottleneck & $\begin{array}{l}\text { Solar } \\
\text { photovoltaic (PV) }\end{array}$ & $\begin{array}{l}\text { PV Insights, Bloomberg } \\
\text { New Energy Finance, } \\
\text { Fraunhofer ISE }\end{array}$ & $\begin{array}{l}\text { Share of cost for components } \\
\text { and complements in solar PV } \\
\text { systems (BOS) }\end{array}$ \\
\hline $\begin{array}{l}\text { Toh and Miller } \\
\text { (2017) }\end{array}$ & Complements & $\begin{array}{l}\text { Communications } \\
\text { equipment }\end{array}$ & Patents & $\begin{array}{l}\text { Jointly cited patents from } \\
\text { different patent classes }\end{array}$ \\
\hline $\begin{array}{l}\text { Kapoor and } \\
\text { Agarwal (2017) }\end{array}$ & $\begin{array}{l}\text { Platform- } \\
\text { ecosystem } \\
\text { complexity }\end{array}$ & Smartphone & $\begin{array}{l}\text { comScore US } \\
\text { smartphone-installed } \\
\text { base database }\end{array}$ & $\begin{array}{l}\text { Sum of the squares of } \\
\text { the monthly shares of the } \\
\text { US-installed base for } \\
\text { smartphone } \\
\text { OEMs }\end{array}$ \\
\hline $\begin{array}{l}\text { Wen and } \\
\text { Zhu (2017) }\end{array}$ & $\begin{array}{l}\text { Platform } \\
\text { complementors' } \\
\text { innovation and } \\
\text { pricing strategy }\end{array}$ & Smartphone & $\begin{array}{l}\text { Mobile app analytics } \\
\text { firm }\end{array}$ & $\begin{array}{l}\text { Updates to smartphone } \\
\text { app and app pricing }\end{array}$ \\
\hline $\begin{array}{l}\text { Agarwal and } \\
\text { Kapoor (2018) }\end{array}$ & $\begin{array}{l}\text { Platform } \\
\text { complementors' } \\
\text { connectedness }\end{array}$ & Smartphone & Apple iTunes & $\begin{array}{l}\text { App's connection with } \\
\text { platform components/ } \\
\text { modules and other apps }\end{array}$ \\
\hline
\end{tabular}

produced by different actors are linked in new ways can have important implications for firms and the underlying architectures.

The organization design choices with respect to activities pertain to how the different activities are organized across firms. What activities firms undertake themselves and what activities are carried out by other firms in the ecosystem represents logics that extend beyond firm-level capabilities and dyadic transaction costs to entail ecosystemlevel complementarities and interdependencies (Gawer and Henderson 2007; Kapoor and Lee 2013; Hannah and Eisenhardt 2017).

Finally, actors in the ecosystem also face the problem of how to design their internal organizations so as to manage the interdependencies with other actors. The buyer-supplier interdependence is managed through well-defined procurement and sales functions on the supply-side and the demand-side respectively. However, the firm-complementor interdependence entails both supply- and demand-side coordination. This amplifies the organization design complexity in terms of the interface that 
manages the interorganizational interdependence between the firm and the complementor and the intra-organizational interdependence between the firm's activities that interact with the complementor's (Kapoor 2014).

To conclude, research on ecosystems represent a vibrant and important research stream for scholars. I hope that this article has presented why such a stream is not only relevant and novel but that it also promises to generate theoretical insights that can create enormous value for both scholars and practitioners.

\section{Endnotes}

${ }^{1}$ Porter (1985) also coins the term "value system" (p. 34) stating that it encompasses the value chains of focal firms, their suppliers, channels, and buyers. While the notion of value system makes explicit the interdependencies between the activities performed by the firm and those by the suppliers, the distributors, and the buyers, the emphasis is still on competitive differentiation and "sequential chains" rather than on the structure of interdependencies and the nature of complementarities.

${ }^{2}$ There are also platforms that facilitate exchange relationships between the different actors (e.g., eBay, Amazon Online Shopping). These "exchange platforms" share many features with "product platforms" that serve as foundations for firms to offer complementary goods or services (Baldwin, 2018d). However, their primary objective is to facilitate exchange between diverse parties rather than to enhance the value of their focal offer (product) through complementors. Accordingly, exchange platforms are not typically subject to considerations of complementarities and interdependencies that are critical for product platforms.

${ }^{3}$ An alternative platform-based nomenclature exists within the product development literature such that the product architecture can entail a platform design, which allows for re-use of components across a family of products targeted at different customer segments and/or product innovations over time. Such internal platforms would be analyzed via product-based ecosystems because the focal offer does not serve as a foundation for other actors to offer complementary products or services to the user.

${ }^{4}$ Relatedly, research on entrepreneurial ecosystems is distinct from that of business ecosystems. Research on entrepreneurial ecosystems focusses on actors that contribute to entrepreneurship in a particular geographical region. The objective here is to understand how the number and the diversity of actors (e.g., start-ups, funders, universities, accelerators) contribute to economic growth as well as the success of start-ups.

\section{Acknowledgements}

I am grateful to the Associate Editor and the two anonymous reviewers for their valuable guidance in improving the article. I also thank Ron Adner, Carliss Baldwin, participants at the Consortium for Research in Strategy Annual Conference and the Organizational Design Community Annual Conference for their helpful comments and suggestions.

Availability of data and materials

Data sharing is not applicable to this article as no datasets were generated or analyzed during the current study.

Author's contributions

The author read and approved the final manuscript.

Competing interests

There are no competing interests. 
Received: 2 July 2018 Accepted: 26 September 2018

Published online: 29 October 2018

\section{References}

Adner R (2012) The wide lens: a new strategy for innovation. Penguin, New York

Adner R (2017) Ecosystem as structure: an actionable construct for strategy. J Manag 43(1):39-58

Adner R, Feiler D (2018) Innovation interdependence and investment choices: an experimental approach to decision making in ecosystems. Organ Sci

Adner R, Kapoor R (2010) Value creation in innovation ecosystems: how the structure of technological interdependence affects firm performance in new technology generations. Strateg Manag J 31(3):306-333

Adner R, Kapoor R (2016) Innovation ecosystems and the pace of substitution: re-examining technology S-curves. Strateg Manag J 37(4):625-648

Agarwal S, Kapoor R (2018) Two Faces of Value Creation in Business Ecosystems: Leveraging Complementarities and Managing Interdependencies, Working paper

Altman EJ (2016) Dependency challenges, response strategies, and complementor maturity: joining a multi-sided platform ecosystem, working paper

Altman EJ, Tripsas M (2015) Product to platform transitions: Organizational identity implications. In The Oxford handbook of creativity, innovation, and entrepreneurship: multilevel linkages. Oxford University Press, Oxford

Ansari S, Garud R, \& Kumaraswamy A (2016). The disruptor's dilemma: TiVo and the US television ecosystem. Strateg Manag J 37(9):1829-1853.

Baldwin, Carliss Y (2018a) Design Rules, Volume 2: How Technology Shapes Organizations: Chapter 5 Complementarity. Harvard Business School Working Paper, No. 19-036, October 2018.

Baldwin CY (2018b) Bottlenecks, modules and dynamic architectural capabilities. In D. J. Teece and S. Heaton (Eds.) The Oxford Handbook of Dynamic Capabilities. https://doi.org/10.1093/oxfordhb/9780199678914.013.011

Baldwin, Carliss Y (2018c) Design Rules, Volume 2: How Technology Shapes Organizations: Chapter 6 The Value Structure of Technologies, Part 1: Mapping Functional Relationships. Harvard Business School Working Paper, No. 19-037, October 2018.

Baldwin, Carliss Y (2018d) Design Rules, Volume 2: How Technology Shapes Organizations: Chapter 14 Introducing Open Platforms and Business Ecosystems. Harvard Business School Working Paper, No. 19-035, October 2018.

Boudreau K (2010) Open platform strategies and innovation: granting access vs. devolving control. Manag Sci 56(10):1849-1872

Casadesus-Masanell R, Yoffie DB (2007) Wintel: cooperation and conflict. Manag Sci 53(4):584-598

Dyer JH (1997) Effective interfirm collaboration: how firms minimize transaction costs and maximize transaction value. Strateg Manag J 18(7):535-556

Ethiraj SK (2007) Allocation of inventive effort in complex product systems. Strateg Manag J 28(6):563-584

Fisher ML (1997) What is the right supply chain for your product? Harv Bus Rev 75:105-117

Ganco M, Kapoor R, Lee GK (2018) Innovation in ecosystems. Working Paper

Gawer A, Cusumano MA (2002) Platform leadership: how Intel, Microsoft, and Cisco drive industry innovation. Harvard Business School Press, Boston

Gawer A, Henderson R (2007) Platform owner entry and innovation in complementary markets: evidence from Intel. Journal of Economics \& Management Strategy 16(1):1-34

Gulati R (1998). Alliances and networks. Strateg Manag J 19(4):293-317

Gulati R, Nohria N, \& Zaheer A (2000) Strategic networks. Strategic management journal, 21(3):203-215

Hannah D (2016) Value creation and capture in a world of bottlenecks. Working Paper

Hannah DP, Eisenhardt KM (2017) How firms navigate cooperation and competition in nascent ecosystems. Strateg Manag J. https://doi.org/10.1002/smj.2750

Hart O, Moore J (1990) Property rights and the nature of the firm. J Polit Econ 98(6):1119-1158

Hawley AH (1986) Human ecology: a theoretical essay. University of Chicago Press, London

Helfat CE, Raubitschek RS (2018) Dynamic and integrative capabilities for profiting from innovation in digital platform-based ecosystems. Res Policy 47(8):1391-1399

Helper S, MacDuffie JP, Sabel C (2000) Pragmatic collaborations: advancing knowledge while controlling opportunism. Ind Corp Chang 9(3):443-488

Henderson RM, Clark KB (1990) Architectural innovation: the reconfiguration of existing product technologies and the failure of established firms. Administrative science quarterly, pp 9-30

Hughes TP (1993) Networks of power: electrification in Western society1880-1930. JHU Press, Baltimore

Jacobides MG, Cennamo C, Gawer A (2018) Towards a theory of ecosystems. Strateg Manag J. https://doi.org/10.1002/smj.2904

Johnson, PF, Mark, Ken (2017) Apple Inc.: managing a global supply chain. Ivey case study

Kale $P$, \& Singh H (2009). Managing strategic alliances: what do we know now, and where do we go from here?. The Academy of Management Perspectives, pp45-62.

Kapoor R (2014) Collaborating with complementors: what do firms do?. In Collaboration and competition in business ecosystems(pp. 3-25). Emerald Group Publishing Limited, Bingley

Kapoor R, Agarwal S (2017) Sustaining superior performance in business ecosystems: evidence from application software developers in the iOS and Android smartphone ecosystems. Organ Sci 28(3):531-551

Kapoor R, Furr NR (2015) Complementarities and competition: unpacking the drivers of entrants' technology choices in the solar photovoltaic industry. Strateg Manag J 36(3):416-436

Kapoor R, Lee JM (2013) Coordinating and competing in ecosystems: how organizational forms shape new technology investments. Strateg Manag J 34(3):274-296

Kapoor R, McGrath PJ (2014) Unmasking the interplay between technology evolution and R\&D collaboration: evidence from the global semiconductor manufacturing industry, 1990-2010. Res Policy 43(3):555-569

Kuhn T (1962) The structure of scientific revolutions. University of Chicago

Lee HL, Padmanabhan V, Whang S (1997) Information distortion in a supply chain: the bullwhip effect. Manag Sci 43(4):546-558

Leontief W (1986) Input-output economics Second Ed. Oxford University Press, New York 
McIntyre DP, Srinivasan A (2017) Networks, platforms, and strategy: emerging views and next steps. Strateg Manag J 38(1): $141-160$

Mentzer JT, DeWitt W, Keebler JS, Min S, Nix NW, Smith CD, Zacharia ZG (2001) Defining supply chain management. J Bus Logist 22(2):1-25

Milgrom P, Roberts J (1990) Rationalizability, learning, and equilibrium in games with strategic complementarities Econometrica 58(6):1255-1277

Moore JF (1993) Predators and prey: a new ecology of competition. Harv Bus Rev 71(3):75-86

Parker G, Van Alstyne MW (2014) Platform strategy. School of Management Research Paper No. 2439323, Boston U. https://doi.org/10.2139/ssrn.2439323

Podolny JM, Page KL (1998) Network forms of organization. Annu Rev Sociol 24(1):57-76

Poppo L, Zenger T (1998) Testing alternative theories of the firm: transaction cost, knowledge-based, and measurement explanations for make-or-buy decisions in information services. Strateg Manag J 19(9):853-877

Porter ME (1985) Competitive advantage: creating and sustaining superior performance. Free Press, New York

Porter ME (1996) What is strategy? Harvard Business Review 74(6):61-78

Rietveld J, Schilling MA, Bellavitis C (2017) Platform strategy: managing ecosystem value through selective promotion of complements. Working Paper

Rivkin JW (2000) Imitation of complex strategies. Manag Sci 46(6):824-844

Rochet JC, Tirole J (2006) Two-sided markets: a progress report. RAND J Econ 37(3):645-667

Siggelkow N (2001) Change in the presence of fit: the rise, the fall, and the renaissance of Liz Claiborne. Acad Manag J 44(4): 838-857

Sterman JD (1989) Modeling managerial behavior: Misperceptions of feedback in a dynamic decision making experiment. Manag Sci 35(3):321-339

Teece DJ (1986) Profiting from technological innovation: implications for integration, collaboration, licensing and public policy. Res Policy 15(6):285-305

Toh PK, Miller CD (2017) Pawn to save a chariot, or drawbridge into the fort? Firms' disclosure during standard setting and complementary technologies within ecosystems. Strateg Manag J 38(11):2213-2236

Van Alstyne MW, Parker GG, Choudary SP (2016) Pipelines, platforms, and the new rules of strategy. Harv Bus Rev 94(4):54-62 Wen W, Zhu F (2017) Threat of platform-owner entry and complementor responses: evidence from the mobile app market. Working Paper

Zobel AK, Hoppmann J, Núñez Jiménez A (2017) Unblocking bottlenecks in nascent innovation ecosystems: how bottlenecks impact firm collaboration. Working Paper

\section{Submit your manuscript to a SpringerOpen ${ }^{\circ}$ journal and benefit from:}

- Convenient online submission

- Rigorous peer review

- Open access: articles freely available online

High visibility within the field

- Retaining the copyright to your article

Submit your next manuscript at $\boldsymbol{\nabla}$ springeropen.com 